\title{
Entrepreneurship Education as Panacea for Unemployment Reduction
}

\author{
M. E. Agwu ${ }^{1}$ \\ ${ }^{1}$ Faculty of Strategy and Entrepreneurship, Lagos Business School, Pan-Atlantic University, Ajah, Lagos State, \\ Nigeria \\ Correspondence: M. E. Agwu, Associate Professor of Strategic Management, Faculty of Strategy and \\ Entrepreneurship, Lagos Business School, Pan-Atlantic University, Km 22, Lekki-Epe Expressway, Ajah, Lagos \\ State, Nigeria.
}

Received: June 4, 2019

Accepted: January 28, 2020

Online Published: February 28, 2020

doi:10.5430/jms.v11n1p37

URL: https://doi.org/10.5430/jms.v11n1p37

\begin{abstract}
Previous studies have affirmed the importance of entrepreneurship education in developing, motivating, and empowering entrepreneurs especially ex-students cannot be over emphasized, because it has led to the positive increase in the existence of entrepreneurs, which, to a great extent, is responsible for the creation of more job opportunities and the reduction of unemployment. Looking at the increasing rate of unemployment, entrepreneurship education has helped in developing entrepreneurs after the classroom, which greatly culminates into curbing the problem of unemployment in in various economies. This study investigated the extent to which entrepreneurship education and its impact in the reduction of unemployment using ex-students four Universities (two private and two public) as a case for the study. With the aid of questionnaire as a data collection instrument, 150 ex-Students currently running their businesses were randomly selected. The Statistical Package for Social Sciences (SPSS) was used to analyze their responses. Findings revealed that the catastrophic problem of unemployment can to a great extent be reduced through educating, motivating, developing, and empowerment of students as entrepreneurs. It also shows that there is a strong relationship between entrepreneurship education and unemployment reduction as most intentions were translated into actions. The results of this study further revealed that practical entrepreneurship classes have helped in motivating students to become entrepreneurs after graduation. Considering these findings, it is recommended that entrepreneurship education, motivation, development and empowerment should be taken serious by the educational institutions in developing economies. And students at all levels should be encouraged to engage in entrepreneurial activities in order to further reduce the rate of unemployment in developing economies. This will enable them to be employers instead of jobseekers.
\end{abstract}

Keywords: Entrepreneurship, Entrepreneurs, Unemployment reduction, Entrepreneurship Education, Nigeria

\section{Introduction}

The increasing rate of unemployment in Nigeria and indeed most developing economies today is alarming, devastating and this has raised concerns among researchers and policy makers. Unemployment has posed itself as a problematic child that is giving government serious concerns in trying to provide a lasting solution to this devastating problem (Ojeifo, 2013). Unemployment has been known to be one of major challenges facing several countries for several decades and this has led to increase in crime rate, mortality rate, poverty rate, and unnecessary dependency on government for paid jobs commonly referred to as white collar jobs (Rosemary, 2016). Despite these problems, entrepreneurship is fast becoming a string of hope for survival, industrialization and wealth creation in various economies such as Nigeria, Kenya, South Africa, and even the developed countries. Entrepreneurship is rapidly proving itself to be a great platform that can be anchored upon to curb the plague of unemployment especially in Nigeria (Agwu, Anidiobu \& Ezinwa, 2016). Although, the Nigerian government, which is presently the highest employer of labor, did put in place various interventions to upscale employment, these efforts have had minimal effects on the state of the economy (Nwachukwu, 2012; Adebisi \& Oni, 2012). This is the reason why as a beam of hope and light for the teaming unemployed, entrepreneurship is advocated by practitioners and academics to be entrenched within the Nigerian education system. It is however believed that entrepreneurship education will assist institutions, organizations, and the governments, to help develop a disciplined, focused and intelligent crop of individuals who are ready and willing to pay the necessary prices, and take the needed risks, to ensure that unemployment rate in is reduced drastically, and the rate of the economic growth is increased. It is worthy to note 
that within the Nigerian fabrics, entrepreneurship is not an alien from another planet, neither is it an abstract that never existed; rather it is a practice that has always been in existence from many decades. It is an unstoppable force that has come to divert our attention back to the ancient landmarks that existed before the emergence of oil within the Nigerian economy (Arah, Mohammed, Ibrahim \& Ajah, 2018). Akojie (2009) cited in Ejemeyovwi (2017) asserts that entrepreneurship is a means through which our formal method of survival as a strong economy is revived and this process has come to draw us back to the drawing board to appreciate the method through which past generations have survived economic challenges and curbed unemployment. This powerful wind of diversification that is blowing is intended to remind Nigerians about the danger of relying on only one source of income or revenue, which is oil, as its proximity to winding up is very close. It was evident that before crude oil was found in Nigeria, and oil wells were being drilled, the economy of Nigeria strived on all kinds of agricultural products, which today forms about $30 \%$ of what is called entrepreneurship (Arah et al., 2018). As at that time, the economy was not at its best state, but it was stable enough for the citizens to have a stable economy and thrive well amid surplus foods and job security. Though revenue generation during this period was very slow and the economy of Nigeria was on a fast lane, there was a change of focus due to massive population growth that was outnumbering the number of jobs available (Enyekit, Dambo \& Enyekit, 2018). As a result of oil becoming a commodity everyone wants to deal on, other means of sustaining the economy like agriculture and entrepreneurship were neglected. Entrepreneurship has been known to have diverse benefits, which ranges from the growth and development of a country, to the rapid stimulation of the drive to do things better which are commonly referred to as innovation (Agwu, Onwuegbuzie, \& Ezeifeka, 2017). Entrepreneurship also brings about the portray of creativity in the development and creation of inventions, it also helps in adding to the existing knowledge of an individual, empowering him/her to venture into researching non existing and beneficial businesses, drugs, and technologies. It is based on these that the famous adage of "Catch Them Young" comes into play (Ubong, 2018). From experience and research findings, one can boldly state that the larger percentage of young people in Nigeria from the age of ten (10) to thirty (30) processes and articulates information very fast, especially when it comes to the practicality of abstracts thinking, information, or and engaging in activities that keeps them for several hours. Concurrently, instilling the act of entrepreneurship into these young generations of youths could be a means to heighten employment generation and thereby reduce the scourge of unemployment (Ubong, 2018; Arah, et al., 2018). This will increase their self-driven motivation and thus drive them to have a sustained motivation to engage in entrepreneurship (Agwu et al, 2017), which will in turn lead to drastic turn down in the level of unemployment. This is the stage at which entrepreneurs are formed through entrepreneurship education. It has been difficult to practically access the impact of these entrepreneurial skills acquired by students within the citadels of learning and the extent to which the knowledge gathered has helped in creating jobs thereby making them employers of labour as opposed to jobseekers. One is bound to ask if entrepreneurship education is worth the while. This paper therefore sets out to investigate the impact of the practicality of entrepreneurship education and evaluate the extent to which it has assisted to reduce the rate of unemployment within the Nigerian polity.

\section{Literature Review}

Of recent, the increasing negative impacts of unemployment on Nigerian youths have become unexplainable. This unemployment variable has created a situation where youths from diverse cultures, backgrounds and religions, who are willing and capable to work, find it very difficult to acquire employment due to under qualification or the devastating effect of god-fatherism occasioned by political corruption in Nigeria (Ebomah, 2006; Aje, 2009). But, it is worthy to note that despite all these, the continuous development and rapt transformation of the Nigerian economy is greatly relying on youth empowerment through entrepreneurship, and this is thrust on effective practical perspective of student entrepreneurship, because every entrepreneur were once motivated by one or more factors during their primary, secondary or tertiary education. These factors are seen as varying in sustaining them in their entrepreneurial journeys. In Nigeria and all over the world, youths are greatly regarded as the strength behind the strategic economic growth and development (Agwu, et al., 2017); likewise, they are highly instrumental during employment and societal reformation. It is for this reasons that there has been call from researchers and practitioners to fan the flame of entrepreneurship education among students who are majorly the bedrock of every society. These dynamic steps will aid their entrepreneurship development which it is hoped to yield employment generation through an effective hands-on entrepreneurship education, motivation and empowerment of these great youths both at the grass root level, and at the dynamic level (Okoye, Iloanya, \& Udunze, 2014).

\subsection{Overview of Entrepreneurship}

Entrepreneurship as a concept, among other subjects and discipline has no singular definition. This implies that entrepreneurship has been viewed differently from various authors and individuals. Holt (1992) cited in Edmund, et 
al, (2011) clearly defined an entrepreneur as an inspired risk taker who is often described as an adventurer that has the power to disrupt society by seizing opportunities and resources for exploitation in unusual ways, and then begin a progress revolution. Entrepreneurship according to Kpelai (2009) is the process of starting, owning, and managing a new venture, or improving an existing product or service that creates value. This value is created by out of the box thinking that is evident in the rebranding or reformation of existing items in order to make such old-fashioned products looks appealing to potential buyers. According to Inegbenebor (1997) cited in Egboh (2009), an entrepreneur can be seen as an individual who craves for change, searches for it, quickly gives undivided attention to it, and leverages on it as an opportunity to advance the economy and this leverage is solely characterized by personal profit maximization. An Entrepreneur can also be seen as an individual who identifies profitable opportunities and is willing to take the risk in a bid to generate a venture or organize a business from it. Furthermore, Ozioko (2006) citied in Agwu, et al., (2016), stressed that entrepreneurship can be seen as an unrelenting nature and inherent ability of an individual in identifying possible opportunities for investment and leveraging on these opportunities to start and successfully run a business enterprise. Stienfioff and Burgers (1993) in Salami (2011) viewed entrepreneurship as the capacity of an individual to start, grow and nurture a new business, or to creatively inculcate innovative ideas into an existing business. According to Adejumo (2000), and Onyeneho \& Ezeano (2011), cited in Okoye, et al, (2014), entrepreneurship can be viewed as an avenue for creating employment opportunities and, wealth creation, because its characteristics has generated so many positive impacts, not only on the nation's economy, but also on the quality of life of the citizens of the country, and it is also responsible for making all the factors of production (which includes; land, labor, and capital), effective and productive. Ronstadt (1984), cited in Kpelai (2009) stated that entrepreneurship is the "dynamic process of creating wealth", and it is the process of creating something distinguishing with value, by devoting the adequate resources, and receiving the equivalent rewards. Entrepreneurship is also seen by Stevenson and Grousbeck (1999) as making maximum use of opportunity, by leveraging on available resources and innovation. They also argued that the distinguishing factor between a business manager and an entrepreneur is the ability to perceive opportunity and the ability to innovate. Okoye, et al, (2014) opined that entrepreneurship is far beyond just beginning an entrepreneurial venture, rather it is a very technical process which involves the continuous identification of opportunities, allocation of resources and value creation, through the identification of needs that are yet to be met, or opportunities available for change. These definitions proposed by different authors above can be summed into the fact as the quest to become an entrepreneur, one must be ready to be innovative, properly financed, possessing outstanding business acumen, see problems as opportunities to be leveraged upon, and then take the necessary step in creating lasting solutions to the identified problems, making it available to the individuals in need of it at a given price.

\subsection{Entrepreneurship Curriculum in Nigerian Educational Systems}

Nigerian universities and indeed all the citadels of learning though were earlier saddled with the responsibilities of motivating economic growth and development through research and development, building entrepreneurial capabilities and competencies has become an added task and important role put on these institutions by the society (Olorundare \& Kayode, 2014). This means that more responsibilities are required of these institutions in other to meet up with the entrepreneurial needs of students to motivate entrepreneurial development potentials (Ifedili \& Ofoegbu, 2011). Specifically, it is important that entrepreneurial development of higher institution students encompasses the development of critical thinking capabilities, business idea generation competencies and a commitment towards the achievement of entrepreneurial goals and aspirations at graduation (Caloghirou, Protogerou, and Deligianni 2013; Gafar, Kasim, and Martin, 2013). Therefore, it is expected that the contents of the entrepreneurship curriculum in Nigerian institutions should motivate individuals that are going to benefit from it. This will help bring about salient entrepreneurial competencies and increase the likelihood of students' engagement in entrepreneurial pursuits at graduation. Empirical studies are awash with the effects of the contents of an entrepreneurship curriculum on the entrepreneurial development of higher institution students from different perspectives. Bodnar and Besterfeild-Scacre (2015) showed the provisions in entrepreneurship curriculum content have implications for entrepreneurial development of higher institution students mainly by motivating critical thinking abilities and business idea generation competencies in students. Mahajar and Yunus (2012) reported in their findings that the role of higher institutions in promoting entrepreneurship development of students is hinged on the provision of entrepreneurial curriculum contents that significantly impacts on students' inclination towards development of critical thinking competencies. In the same vein, Gafar, Kasim and Martin (2013) results showed that entrepreneurship curriculum in the tertiary institutions affects entrepreneurial development of students by motivating undergraduates as well as postgraduate students to develop innovative business ideas. In the Nigerian higher institutions' context, Ebringa, Ewenwa and Ebringa (2015) suggests that entrepreneurial development involves the 
engagement of students in practical and collaborative entrepreneurial extra curricula activities and mentoring by experienced entrepreneurial minded academics and practitioners which equips students with critical thinking competencies favorable to entrepreneurial venturing upon graduation. Conversely, the findings from the work of Caloghirou, Protogerou, and Deligianni (2013) which focused on entrepreneurial development among students and young higher institutions graduates showed that an entrepreneurship curriculum content that does not motivate entrepreneurial actions and real life simulations of the process of entrepreneurship will negate the drive and commitment of young graduates in terms of setting up entrepreneurial ventures. It is evident from these reviews that entrepreneurship curriculum content goes a long way to bringing about a critical mindset among students who are considered potential entrepreneurs. Based on this it is therefore hypothesized thus:

Hypothesis 1

- $\mathrm{H}_{0}$ : Student Entrepreneurship cannot help to reduce unemployment in Nigeria.

- $\mathrm{H}_{1}$ : Student Entrepreneurship can help to reduce unemployment in Nigeria.

\subsection{Student Entrepreneurship and Unemployment}

Students' practical entrepreneurship activities can be a significant factor in unemployment reduction if the channels through which the trainings are given are well tailored towards instilling an entrepreneurship mindset among the students. Empirically, numerous studies have shown the significance of student entrepreneurship and how it has reduced unemployment in many contexts and other countries. For example, Fajana (2000) states that unemployment is an unpleasant problem in an individual's life where despite the willingness and ability to work, finds it difficult to acquire a suitable paying job. The increasing rate of unemployment in Nigeria is constantly calling for the attention of the Federal Government of Nigeria, to create lasting solutions to this problem, because the higher the rate of unemployment within the federation, the higher the level of poverty, crime, death rate, and other problems associated with unemployment. Therefore, there is a dying need for entrepreneurship development and more entrepreneurs. It has also been proven that entrepreneurship has been found to be an un-ignorable variable in the equation of developing countries economic growth and development, and it has been recorded to be a permanent cure for unemployment and its devastating effects. The term entrepreneurship is multidimensional in its approach. According to Salami (2011), one of the foremost reason unemployment is growing rapidly in Nigeria is because, youths cannot match the requirements for employment, they are unskilled, and they do not have adequate practical knowledge and experience on how to be independent, especially as regards leveraging on entrepreneurship. It is based on this that the educational system has been saddled with the task to give youths an intuitive alternative which involves educating and empowering them to become independent by being entrepreneurs that do not rely on white collar jobs or government jobs. This action is being implemented through hands-on training and skill acquisition, directed at creating employment and drastically reducing dependency on the government for survival. Salami (2011) also stated that the culture of entrepreneurship should be imbibed in the heart of the youths, coming from the educational background, which is student entrepreneurship, and there should be a concurrent shift from the old system of education to a new one which inculcates vocational and technical training into its curriculum, so as to begin this entrepreneurial intervention from the grass root of our nation's economy. According to Dike, (2009) cited in Salami, (2011), technical education is the combination of scientific knowledge and acquisition of skills, which is developed through a formal education system for the purpose of building a strong economy through innovations.

Chinonye, Oludayo, Akinbode, Agboola, Oluyomi, Oluwatobi and Chugamonu, (2015) clearly stated that student entrepreneurship should be a process that will not only teach students theories and findings, but also practically train them to enable them create wealth for themselves and become self-employed, which will reduce the rate of unemployment and boost the economy. They also argued that training programmes should not be jeopardized but should be carefully designed to equip individuals with innovative, technical, creative, and practical skills required to run an enterprise successfully, and creating more job opportunities in the process. In support of this postulation, Okifo (2013) in Chinonye, et al, (2015), states that the Nigerian Federal Ministry of Education has directed that entrepreneurship education become a compulsory part of tertiary institution's curriculum. In response to this, various tertiary institutions have started inculcating and generating entrepreneurship training classes and vocational workshops in a bid to curb unemployment in Nigeria. Most times, this has helped in developing student entrepreneurs who not only begin these entrepreneurial ventures in school, but still nurture it to becoming a foundation for employment generation, wealth creation, poverty alleviation and unemployment reduction. Operationally, student entrepreneur is described in this study as individual in a formal educational setting who has been educated, motivated, encouraged and empowered to start a business while still in school and diligently grows and nurtures the business to the stage whereby it can be a foundation for employment generation in future. A student 
entrepreneur is one who starts a business while in school, develops innovative ideas to keep the business growing and continues with the business after graduation. It is hoped that this employment instinct in a student entrepreneur will be an avenue to create job opportunities for job seeking individuals. Because, student entrepreneurs are self-employed and independent, they are creative thinkers and risk takers through trainings, the scourge of unemployment is believed to be minimized through their modelling ability that is expected to be passed on to next generation of students. Based on this it is therefore hypothesized thus:

Hypothesis 2

- $\mathrm{H}_{\mathrm{o}}$ : Student Entrepreneurship has not helped in reducing unemployment in Nigeria.

- $\mathrm{H}_{1}$ : Student Entrepreneurship has helped in reducing unemployment in Nigeria.

\section{Methodology and Methods}

The quantitative reasearch design was used in carrying out this study and this signifies the development of numerical data from an acceptable number of adminsitered questionnaires. The population that was considered for this study were final year students of four universities (two private and two public universities) expecting to graduate in 2018. In determining a sample size, a random selection of 150 students were selected to fill out the questionnaire, out of which 145 was returned and 140 found useful for analysis, yielding a response rate of 93.3\%. As regards the participant demographics, $48(32 \%)$ were females while $52(78 \%)$ were males. Their mean age is 27.5 with P.gd/MSc/MBA/M.Eng/M.A (64.3\%) educational qualification in view. In checking the reliability of the 13 item research instrument, the Cronbach Alpha method was used and the instrument yielded a Cronbach Alpha of .79. The Statistical Package for Social Sciences (SPSS) was also used to analyze responses and derive conclusions.

\section{Data Analysis}

The research questions were analyzed, and the results obtained were presented below. The Likert Scale statements received varying degrees of responses as stated below:

There is a strong relationship between ex-student entrepreneurship and unemployment reduction in Nigeria: The responses of the respondents to the statement show that 47.1\% (66) strongly agrees, 39.3\% (55) agree, 7.1\% (10) were undecided, 5.0\% (7) disagree, and 1.4\% (2) strongly disagrees. Based on this analysis, respondents strongly agree that there is a strong relationship between student entrepreneurship and unemployment reduction.

Ex-students entrepreneurship can help reduce unemployment in Nigeria: Based on the analysis, it was clear that $48.6 \%$ (68) of respondents strongly agree 42.9\% (60), agrees, 5.7\% (8) were undecided, 2.1\% (3) disagree, and $0 \%$ (0) strongly disagree. In line with this analysis, respondents strongly agree that student entrepreneurship can help reduce unemployment.

Practical Entrepreneurship classes can help in motivating ex-students to become entrepreneurs: Based on this, 47.9\% (67) strongly agrees, 45.0\% (63) agree, 4.3\% (6) were undecided, $2.1 \%$ (3) disagree, and $0.7 \%$ (1) strongly disagree. Based on this analysis, respondents strongly agree that practical entrepreneurship classes can help in motivating students to become entrepreneurs.

Ex-students develop intentions to be self employed after taking entrepreneurship classes: It was observed that $25.7 \%$ (36) of respondents strongly agree, 45.0\% (63) just agree, 16.4\% (23) were undecided, 10.0\% (14) disagree, and $2.1 \%$ (3) strongly disagree. Therefore, it was concluded that the respondents agree that students develop intentions to be self-employed after entrepreneurship classes.

Have you been motivated to start your own business after undergoing entrepreneurship classes and vocational trainings? It was observed that the responses of the respondents to the statement shows that 32.9\% (46) strongly agree, 46.4\% (65) agree, 10.7\% (15) were undecided, 8.6\% (12) disagree, and 1.4\% (2) strongly disagrees. Based on this analysis, respondents agree to the fact that they have been motivated to start their own business after undergoing entrepreneurship classes and vocational trainings. Entrepreneurship education has helped in reducing unemployment in Nigeria: Analysis shows that 30.7\% (43) of respondents strongly agree, 41.4\% (58) agree, 17.1\% (24) were undecided, $10.0 \%$ (14) disagree, and $0.7 \%$ (1) strongly disagrees. Therefore, the respondents agreed that entrepreneurship education has helped in reducing unemployment in Nigeria.

Entrepreneurship classes during school days have helped in forming focused, diligent and hardworking ex-student entrepreneurs: The responses show that 32.1\% (45) strongly agree, 49.3\% (69) agree, 12.9\% (18) were undecided, $5.0 \%$ (7) disagree, and $0.7 \%$ (1) strongly disagree. Based on this analysis, respondents agree to the fact that student entrepreneurship has helped in forming focused, diligent and hardworking student entrepreneurs. 
Businesses started by ex-students have grown to become a foundation for employment: Responses shows that $25.0 \%$ (35) of respondents strongly agree, 50.0\% (70) agree, 20.7\% (29) were undecided, 3.6\% (5) disagree, and $0.7 \%$ (1) strongly disagrees. Therefore, it can be concluded that the respondents agree that business started by students have grown to be a foundation for employment.

Ex-students are motivated and empowered to start their own business due to the wealth of knowledge gained through entrepreneurship classes: The responses on this shows that $27.9 \%$ (39) of the respondents strongly agree, 54.3\% (76) agree, $17.1 \%$ (24) were undecided, $10.0 \%$ (14) disagree, and $0.7 \%$ (1) strongly disagrees. Therefore, the respondents agree that students are motivated and empowered to start their own business due to the wealth of knowledge gained through student entrepreneurship.

Entrepreneurship Education has fully equipped you to become an entrepreneur and be successful in any entrepreneurial venture of your choice: Respondents were very clear with that fact that 29.3\% (41) strongly agree, $45.7 \%$ (64) agree, $17.1 \%$ (24) were undecided, 5.7\% (8) disagree, and 2.1\% (3) strongly disagree. Based on this analysis, respondents agree to the fact that entrepreneurship education has fully equipped them to become entrepreneurs and be successful in any entrepreneurial venture.

Test of Hypothesis 1: Statement of Hypothesis:

- $\mathrm{H}_{\mathrm{o}}$ : Student Entrepreneurship cannot help to reduce unemployment in Nigeria.

- $\mathrm{H}_{1}$ : Student Entrepreneurship can help to reduce unemployment in Nigeria.

The test statistics to be used in this hypothesis is the regression analysis. The significance level below 0.05 implies a statistical confidence of above 95\%. Therefore, we reject the null hypothesis once the P-value is $\leq 0.05$ and accept the alternative hypothesis:

Table 1. Model summary

\begin{tabular}{lllll}
\hline Model & $\mathrm{R}$ & R Square & Adjusted R Square & Std. Error of the Estimate \\
\hline 1 & $.244^{\mathrm{a}}$ & .059 & .052 & .976 \\
\hline
\end{tabular}

a. Predictors: (Constant), Student Entrepreneurship can help reduce unemployment in Nigeria

Table 2. ANOVA ${ }^{\mathrm{a}}$

\begin{tabular}{lllllll}
\hline Model & & Sum of Squares & df & Mean Square & F & Sig. \\
\hline \multirow{2}{*}{1} & Regression & 8.182 & 1 & 8.182 & 8.584 & $.004^{\mathrm{b}}$ \\
\cline { 2 - 6 } & Residual & 129.644 & 136 & .953 & & \\
\cline { 2 - 6 } & Total & 137.826 & 137 & & & \\
\hline
\end{tabular}

a. Dependent Variable: Students develop intentions to be self employed after taking entrepreneurship classes

b. Predictors: (Constant), Student Entrepreneurship can help reduce unemployment in Nigeria

The results from the table shows the extent to which the variance reduces unemployment in Nigeria was explained by student entrepreneurship at $5.9 \%$ i.e. $(\mathrm{R}$ square $=0.059)$. From the anova table, the null hypothesis was rejected because the P-value is less than 0.05 . The model in this table reaches statistical significance $($ sig $=0.004)$, in which the P-value is equal to .004 , and less than 0.05 . Therefore, the null hypothesis is hereby rejected. This implies that "Student Entrepreneurship can help to reduce unemployment in Nigeria". Therefore, the alternative hypothesis is accepted.

Test of Hypothesis 2: Statement of Hypothesis:

- $\mathrm{H}_{\mathrm{o}}$ : Student Entrepreneurship has not helped in reducing unemployment in Nigeria.

- $\mathrm{H}_{1}$ : Student Entrepreneurship has helped in reducing unemployment in Nigeria.

Based on the regression analysis utilized for this hypothesis, the significance level was below 0.05 which implies a 
statistical confidence of above 95\%. Therefore, the null hypothesis is rejected since the P-value is $\leq 0.05$ and the alternative hypothesis accepted.

Table 3. Model summary

a. Predictors:

\begin{tabular}{lllll}
\hline Model & $\mathrm{R}$ & R Square & Adjusted R Square & Std. Error of the Estimate \\
\hline 1 & $.376^{\mathrm{a}}$ & .141 & .135 & .759 \\
\hline
\end{tabular}

Entrepreneurship education has helped in reducing unemployment in Nigeria

(Constant),

Table 4. ANOVA ${ }^{\mathrm{a}}$

\begin{tabular}{|c|c|c|c|c|c|c|}
\hline & & Sum of Squares & $\mathrm{df}$ & Mean Square & $\mathrm{F}$ & Sig. \\
\hline & Regression & 13.087 & 1 & 13.087 & 22.698 & $.000^{\mathrm{b}}$ \\
\hline 1 & Residual & 79.563 & 138 & .577 & & \\
\hline & Total & 92.650 & 139 & & & \\
\hline
\end{tabular}

a. Dependent Variable: Businesses started by students have grown to be a foundation for employment

b. Predictors: (Constant), Entrepreneurship education has helped in reducing unemployment in Nigeria

The Regression analysis used in evaluating hypothesis 2 shows how much of the dependent variable variance is explained by the model. The results from the table shows the extent to which the variance in reducing unemployment in Nigeria is explained by student entrepreneurship at $37.6 \%$ i.e. (R square $=0.376$ ). The Anova table reveals the assessment of the statistical significance of the result. The null hypothesis is rejected because the P-value is less than 0.05. The model in this table reaches statistical significance ( $\mathrm{sig}=0.000$ ), in which the P-value is equal to .000, and less than 0.05 . Therefore, the null hypothesis is rejected. This implies that "Student Entrepreneurship has helped in reducing unemployment in Nigeria". Therefore, the alternative hypothesis is accepted.

\section{Discussion of Findings}

This study is focused on entrepreneurship education and unemployment reduction in Nigeria. It considered and analyzed responses from 150 respondents of ex-students of four universities (two private and two public universities) in Nigeria. Among others it sought to understand if an effective practical entrepreneurship education has helped in developing student entrepreneurs after graduation, which will have a ripple effect on reducing unemployment among youths in Nigeria and reduces absolute dependency on sparse government jobs. There has been entrepreneurship curriculum development within the Nigeria education system in recent years; this was carried out in order to introduce more functional subjects as opposed to theories passed down by the colonial masters. The universities were chosen for the study because they have strong entrepreneurship curriculum which also covers practical classes on entrepreneurship that includes but not limited to fish farming, snail rearing, poultry farming, bag making, hair dressing, cosmetics, fashion designing, painting, printing and publishing, water production, pet blowing and event management. These practical curriculum covers a series of areas that can be leveraged upon by students in a bid to become successful independent entrepreneurs after graduation, it is hoped that the range of success of these entrepreneurship programs will bring about the effect which will drastically reduce unemployment. Based on the findings of the study, it is clear cut that there is a strong relationship between ex-student entrepreneurship and unemployment reduction. Practically, student entrepreneurship can help develop intentions and motivate students to become self-employed entrepreneurs who will be self-motivated to help in reducing unemployment. This is in line with Chinonye, et al, (2015) study which asserts that student entrepreneurship is aimed at teaching students the practical application of business theories and findings, and practically train and empower them to enable wealth creation through self-employment. It was also discovered that the respondents developed a positive mindset towards entrepreneurship because the entrepreneurship education that they have undergone, has fully equipped them with the needed skills, tactics, strategies and composure, to be able to manage any entrepreneurial venture they decide to run. This finding validates the effort of the Nigerian Federal Ministry of Education cited in Chinonye, et al, (2015), that directed that entrepreneurship education become a compulsory part of tertiary institution's curriculum from 
2007/2008 academic session onwards, which have gone a long way to stimulating the efforts of various tertiary institutions around the nation to start inculcating and generating entrepreneurship training classes and vocational workshops, in a bid to do their little best in trying to curb unemployment in Nigeria. The findings of the study also indicated that there is high possibility for employment generation through ex-student entrepreneurship; this is because when student entrepreneurs graduate, they may start and continue their trade or businesses with the hope of expanding it beyond their expectations. The finding is in tandem with Akpomi (2010) position that developed countries like Norway were able to enhance their economy and employment generation by mobilizing their youths for enhanced creativity which is in support of the national development. Unemployment has been positively related with high crime rates which are found to be negatively correlated with student entrepreneurship. Student entrepreneurs act as job creators and through these means, social vices like high crime rates are combated. This paper argues that student entrepreneurship is significant factors that enhances creativity among students and lead them to be self-dependent and then become employers of labor rather than seek for sparse white-collar jobs.

\section{Conclusion and Recommendations}

Based on the analysis of the responses from the respondents to the distributed questionnaires, it can adequately be concluded that ex-students entrepreneurship activities are very instrumental in curbing the unemployment problem of Nigeria, through training and empowering of youths to become self-employed and sharpen their skills in identifying lucrative opportunities that will shift a total dependence on government and white collar jobs to entrepreneurship and self-reliance. This paper therefore recommends that more unrelenting effort should be put in by the government, tertiary institutions, and capable individuals, to ensure that youths are adequately trained to be creative and self-reliant through the non-exhaustive effort of ensuring that entrepreneurship is not just taught in every tertiary institutions within the nation, but practical vocational trainings and empowerment should be practiced. It is also the recommendation of this paper that student's entrepreneurship education should not just be centered on tertiary institutions alone, but also the entrepreneurship education should also be extended to secondary schools around the nation.

\section{References}

Adebisi, T. A., \& Oni, C. S. (2012). Assessment of relevance of National Directorate of Employment training programme to the needs of the trainees in South-West in Nigeria. International Journal of Vocational and Technical Education, 4(3) 29-37.

Adejumo, G. (2001). Indigenous Entrepreneurship Development in Nigeria: Characteristics, Problems and Prospects. Advances in Management: Journal of Department of Business Administration, University of Ilorin, Ilorin Nigeria, 2(1), 112-122.

Agwu, M. E., Onwuegbuzie, H. N., \& Ezeifeka, P. (2017). Impact of Entrepreneurship Education on New Ventures Creation-A Case Study. Advances in Social Sciences Research Journal, 4(25).

Agwu, O., Anidiobu, G., \& Ezinwa, C., (2016). Entrepreneurship Education: A Panacea for Unemployment in Nigeria. Journal of Social Development, 5(2).

Aje, E. N. (2009). Entrepreneurial education in snail farming and bee-keeping as a viable rural community development strategic option for Nigeria. Journal of National Association of Female Teachers, 1(1), 29-35.

Akpomi, M. E. (2010). Preparedness of national youth service corps (NYSC) members in south-south Nigeria for entrepreneurship. Business Education Journal, 7(2), 226-238.

Arah, A. S., Mohammed, E. M., Ibrahim, A. M., \& Ajah, A. O. (2018). Entrepreneurial Barriers and Intentions Among Final Year Undergraduate Students Of Industrial And Technology Education In Niger And Kaduna States, Nigeria. Journal of Science, Technology and Education, 6(1), 178-187.

Bodnar, A. C., Renee, M. C., \& Mary, B. S. (2015). Lessons learned through sequential offerings of an innovation and entrepreneurship boot camp for sophomore engineering students. Journal of Engineering Entrepreneurship, $6(1), 52-67$.

Caloghirou, Y., Protogerou, A., \& Deligianni, I. (2013). "How could education systems cultivate knowledgeintensive entrepreneurship? An example from engineering education". New Ventures Creation - A Case Study. Advances in Social Sciences Research Journal, (425), 98-114.

Chinonye, M., Oludayo, O., Akinbode, M., Agboola, M., Oluyomi, O., Oluwatobi, S., \& Chugamonu, U. (2015). Entrepreneurship Education and Poverty Alleviation: Impact Analysis of Covenant University Graduate between 2006- 2013. International Conference on African Development Issues (CU-ICADI): Social and Economic Models for Development Track 
Dike, V. (2009). Addressing Youth Unemployment and Poverty in Nigeria: A call for Action, Not Rhetori. Journal of Sustainable Development in Africa, 11(3), 129- 151.

Ebomah, E. M. (2006). An approach to sustainable entrepreneurship development in Nigerian economy: issues and prospects. Journal of Business Education, 1(1), 65-69.

Ebringa, A. S., Ewenwa, O. A., \& Ebringa, S. F. (2015). Entrepreneurship education in Nigerian Universities: A Tool for National transformation. Asia Pacific Journal of Educators and Education, 29, 155-175.

Edmund, E., \& Ezeano, V. (2011). Entrepreneurship: A Fundamental Approach (1st ed.). Enugu, John Jacob's Classic Publishers Ltd.

Egboh, S. H. (2009). Entrepreneurship Development for Employment and Wealth Creation (1st ed.). Delta, Ehis Print.

Ejemeyovwi, J. O. (2017). Information And Communication Technology Adoption And Inclusive Growth In West Africa. Doctoral dissertation, Covenant University, Ota, Nigeria.

Enyekit, E. O., Dambo, B. I., \& Enyekit, K. E. O. (2018). Entrepreneurship Education In Nigeria; A Traingular Approach For Its Workability. Nigerian Journal of Business Education, 4(2), 349-356.

Fajana, S. (2000). Functioning of the Nigerian Labor Market. Lagos. Labonfin and Company.

Gafar, M., Kasim, R., \& Martin, D. (2013). Development of FM entrepreneurial assessment model to examine effect of entrepreneurship education on the real estate management students. African Journal of Business Management, 5(26), 10707-10717.

Ifedili, C., \& Ofoegbu, F. (2011). Managing entrepreneurship education in Nigerian Universities. European Journal of Educational Studies, 3(1), 1946-6331.

Kpelai, S. (2009). Entrepreneurship Development In Nigeria (1st ed.). Benue, Aboki Publishers.

Mahajar, A. J., \& Yunus, J. M. (2012). Factors that encourage women involvement in SMEs in Pahang, Malaysia. The Journal of Human Resource and Adult Learning, 8(2), 33-41.

Nwachukwu, I. (2012). Nigeria's unemployment rate at 23.9\% in 2011. Retrieved August 20, 2014, from http://business day online.com/NG/index.phb/economic

Odunuga, A. (2015). Trickling down youth unemployment in Nigeria by leveraging on Entrepreneurial Education. Third Annual International Conference on Sustainable Development (ICSD), Columbia University, New York

Ojeifo, S. A. (2013). Entrepreneurship Education In Nigeria: A Panacea For Youth Unemployment. Journal of Education and Practice, 4(6).

Okifo, A. (2013). Entrepreneurship Education: A Key to Solving Graduate Unemployment in Niger-Delta. Standard Journal of Education and Essay, 1(5), 69-75.

Okoye, N., Iloanya, K., \& Udunze, U. (2014). Youth Unemployment and Entrepreneurship Development: Challenges and Prospects in Nigeria. Kuwait Chapter of Arabian Journal of Business and Management Review, 4(4), 1-7.

Olorundare, A. S., \& Kayode, D. J. (2014). Entrepreneurship education in Nigerian Universities: A Tool for National transformation. Asia Pacific Journal of Educators and Education, 29, 155-175.

Onyeneho, E., \& Ezeano, N. (2011). Entrepreneurship: A Fundamental Approach. Enugu, John Jacob's Classic Publisher Ltd.

Ozioko, H. (2006). Self-employment: A panacea to unemployment. Uyo: Afahaid and Bros.

Paul, E. (2005). Entrepreneurship in Vocational Education. Enugu. Ozybel Publishers.

Rosemary, E. N. (2016). Entrepreneurship Education for Self-reliance and Economic Development in Nigeria. International Journal of Vocational and Technical Education Research, (2), 9-14.

Salami, C. (2011). Entrepreneurship and Youth Unemployment in Nigeria: The Missing Link. Global Journal of Management and Business Research, 11(5), 1-7.

Salami, C. (2013). Youth Unemployment in Nigeria: A time for creative intervention. International Journal of Business and Marketing Management, 1(2), 18-26.

Stevenson, H., \& Grousbeck, H. (1999). New Business Ventures and Entrepreneurs. Homewood, Ill: Irwin.

Ubong, B. (2018). Entrepreneurship Education In Nigeria: Issues, Challenges, And Strategies. Nigerian Journal of Business Education, 4(1), 11-22. 